\title{
The impact of graduate training on teachers and schools - two case studies: graduate teachers' perceptions $^{1}$
}

\author{
Ana Rita Faria ${ }^{a}$ \\ Pedro Guilherme Rocha dos Reis ${ }^{b}$ \\ Maria Helena Peralta ${ }^{c}$
}

\section{Abstract}

The main goal of this study is to research the impact of enrolment in Graduate Programmes (GPs) on a set of Basic Education ${ }^{2}$ and High School ${ }^{3}$ teachers in Portugal. We seek to understand whether teachers consider this training as an added value, and the extent to which this is reflected in the improvement of their professional performance, in the schools, and in their students' learning. Preliminary research results show, among other aspects, that the reasons why teachers enrol in GPs are associated mainly with personal fulfilment issues. Moreover, despite the fact that both teachers and school leaders recognize the importance of GPs, they acknowledge that there are still few effects.

Keywords: Graduate training. Teachers. Impact assessment. Curriculum.

\section{Introduction}

This study is the result of a reflection and analysis process over the last three years within the scope of a doctoral thesis in education with a specialization in Curriculum Theory and Development funded by the Fundação para a Ciência

\footnotetext{
a Universidade de Lisboa. Instituto de Educação. Lisboa, Portugal.

b Universidade de Lisboa. Instituto de Educação. Lisboa, Portugal.

c Universidade de Lisboa. Instituto de Educação. Lisboa, Portugal.

1 Research Project financed by Fundação para a Ciência e Tecnologia (FCT) through doctoral research Grant (SFRH/ BD/ 87243/ 2012).

2 Basic Education includes three cycles: 1st cycle with a four-year duration - attended by children from age 6; 2nd cycle, including grades 5 and 6, usually attended by children ages 10 and 11; 3rd cycle, including grades 7, 8, and 9, attended by children ages 12 to 14 .

3 High School has a three-year duration - grades 10,11, and 12 - usually attended by teenagers ages 15 to 17 .
} 
e Tecnologia (FCT). It is part of a broader research project led by the Centre for Education and Human Development at the Portuguese Catholic University and by the Institute of Education, University of Lisbon, coordinated by Professor $\mathrm{M}^{\mathrm{a}}$ do Céu Roldão, including national and international researchers. This wider research project focuses on the characterization, distribution and enhancement of Graduate Programmes (GPs) for teachers in the Portuguese educational system. In order to pursue this research strand, this study arose from the need to develop in-depth studies in order to analyse and evaluate the effects of the different GPs attended. Thus, the main goal of this study is to research the impact of the enrolment in GPs on a set of school teachers from a School Cluster and in a Private School in Portugal. Our aim is to understand whether teachers consider this training as an added value and the extent to which this is reflected in the improvement of their professional performance, in the schools themselves, and in the students' learning.

Within this research problem we defined four research questions:

1. What are the teachers' perceptions regarding the GPs they attended?

2. What are the effects of the GP attended on the school, the classroom and on research practices?

3. What is the added value from enrolling in a GP for the teachers and the participating institutions?

4. What effects do teachers' GPs have on the improvement of education and schools?

These research questions were operationalized in the following objectives: 1) by characterizing the curricular profile of the different GPs attended by the teachers; 2) by pinpointing how teachers mobilize the knowledge and skills acquired in their GPs in schools; 3) by characterizing the pedagogical practices of the participating teachers and establishing the possible relationship of these practices with the mobilization of knowledge acquired through their GP; 4) by analysing the impact of GPs on the teachers actions at three professional levels: classroom (micro-impact), schools (meso-impact) research and educational practices within their community (macro-impact); 5) by evaluating how the school takes advantage (or not) of the knowledge and skills developed by teachers through their GPs.

This study also aimed to present a set of recommendations for Institutions of Higher Education and Schools, which may provide a basis for reflection in the 
design of GPs for school teachers, with a view to enhancing their impact on schools and their use by school administration.

Given this research design, it is pressing to disseminate the results, albeit preliminary, based on the analysis of the questionnaires applied in the participating institutions as well as the teachers' interviews, while also providing the opportunity to advance some considerations on the profile of GPs attended by teachers.

\section{Theoritical framework}

\subsection{Curriculum and pedagogy in higher education}

Bringing curriculum into discussion is putting forward one of the most important concepts sustaining educational practices, enabling us to understand how it unfolds in an educational context, whether in classrooms, (SACRISTÁN, 2000), in a broader context encompassing the whole school or in vocational training.

However, there are many existing definitions of curriculum (for example, CARR, 1993; DOYLE, 1992; GRESS; PURPEL, 1978; JESUS, 2008; LEWIS, 1902; PACHECO, 2003; PERALTA 2005; ROLDÃO, 1999, 2005; SACRISTAN 2000; ZABALZA, 2001), depending on how each educational actor understands the dynamics of the teaching and learning process (PERALTA, 2005), considering many differences in terms of scope and accuracy (ESTRELA, 2011). There are as many definitions of this concept as several documents have been written on the subject (GRESS; PURPEL, 1978); however, none of them fully portray the meaning associated with its use (DOYLE, 1992). Furthermore, many of these definitions are situated only at the school level, often revealing conflicting differences between the way of thinking and organizing the educational institution (GASPAR; ROLDÃO, 2007).

Taking the diversity of curriculum concepts into account, and given the existing convergences between different frames of reference, the definition of curriculum includes what will be learned, why, its purpose, and which strategies to use in order to promote learning. Hence, curriculum is translated into a model that explains what should be taught and learned, including the answers to the following questions: what?, who?, why?, when?, and how? (ibidem).

Discussing curriculum is also discussing a political construction combined with a social and historical construction. It includes discussing innovations, reforms and changes to which the curriculum itself is not immune (PERALTA, 2012). This issue leads us to Bologna as an example of a reform in higher education 
upon which most of this research is focused. It is precisely the importance that higher education assumes in the knowledge society, and its reform fuelled by the Bologna Declaration, that contributes to its prominence, even if this has still not been fully explored in research (TRINDADE, 2010).

The Bologna Declaration, signed on 19 June 1999, established European guidelines for universities, emerging as a political response to the construction of a knowledge society, characterized by globalization and advanced technologies, where competitiveness is emphasized (ESTRELA, 2011). Therefore, these educational paradigm shifts (ESTRELA, 2011; REIS; CAMACHO, 2009;) require not only political changes, but also ethical and pedagogical reforms within higher education (ESTRELA, 2011).

The Bologna Declaration has played a key role in the reform and in the changing of the different curriculums, which were rooted in tradition and routine, which, in turn, also presents us with a reform of the way we look at higher education (CUNHA, 2009).

Higher Education pedagogy should question policies and society. Questioning the pedagogy of higher education is assuming it as a domain with multiple dimensions and a specific complexity, implying expectations and influences of various origins (ESTEVES, 2008), considering that "the goal of transforming pedagogy is an education towards emancipation" (VIEIRA, 2005, p. 14). Within this framework, the foundation of a university pedagogy is the existence of knowledge that is simultaneously learned and taught (ESTEVES, 2008), this being the possible and desirable way, but also subject to changes through questioning (VIEIRA; SILVA; ALMEIDA, 2009).

In short, curriculum is not only what must be learned, just as pedagogy is not simply how to teach a particular content (CORBETT; NORWICH, 2005). In this context, the adopted definition considers curriculum as a set of learned skills and competences developed by the learner throughout the whole formal learning process, which are historically and socially contextualized. On this basis, we adopted a perspective of reflection on the curriculum and its impact. Therefore, analysing the effects of the programmes on teachers requires, on the one hand, understanding the importance given to the experienced curriculum, and on the other, questioning the effects of the curriculum on their professional performance. This implies an in-depth analysis of GPs curriculums, evaluating whether how what is done, and the way it is done, may be an effect of the curriculum. 


\subsection{Graduate education}

Nowadays, teachers are more than experts in their fields of knowledge,; they are required to know a lot about multiple areas. More than just being a transmitter of knowledge, they have responsibilities at psychosocial and psycho-sociological levels (CUNHA, 2008). The increased demands of the teaching profession require a constant update of knowledge and techniques (LEITE, 2013). Nevertheless, it should be noted that teachers' initial training requirements in Portugal have been reduced, while simultaneously new demands have emerged, requiring initial teacher training ${ }^{4}$ institutions to adjust their in-service training strategies and to establish them as a new priority. Thus, increased investment in GPs, essential for the performance of specific functions (CAMPOS, 1995), the promotion of a higher quality of training that transcends initial teacher training and the educational fields to which each teacher is linked, are duly justified (LEITE, 2005).

Therefore, GPs have taken on an essential role as a fundamental support to teacher training, as well as to the production of knowledge that triggers the scientific and technological development of the country (CURY, 2004). Moreover, the demographic changes and technological evolution have caused shifts in terms of numbers regarding teaching and learning reflected in the growth in demand for GPs and the need for changes to this training towards a requalification of the population (POUZADA et al., 2003).

The supply and demand of GPs in education dates back to the eighties, due to interest, on the part of teachers, in increasing their initial training knowledge, attaining a new academic qualification, career advancement, in addition to developing new skills for the performance of specific functions, either as teachers or in other educational contexts (CAMPOS, 1995). According to Cury (2004), the main goal of initial teacher training is geared towards teachers' professionalization, with particular emphasis on their professional employability.

Within the Portuguese context of higher education, there is still the idea that

Portuguese higher education is at the forefront of one of the most critical challenges in the country: the higher qualification of its human resources, and its scientific and technological groundwork. [...] Our scientific and academic development is still very fragile. There is tremendous social resistance to a culture of persistent, serious, demanding and critical work, without which there can be no scientific or technological development (BRASIL, 2010, p. 11).

${ }^{4}$ We have adopted the expression "teacher training" because it is the term used institutionally in Portugal. 


\subsection{Evaluating the impact of training}

Evaluation is an information gathering process, that can be more or less elaborated (FERNANDES, 2010) allowing us to make judgments about the value or merit of a given object (BARBIER, 1985; FERNANDES, 2009, 2010; FITZPATRICK; SANDERS; WORTHEN, 2004; PEREIRA; COSTA, 2004).

In fact, research on the evaluation of GPs, in Portugal, as well as initiatives at an institutional level began in the nineties, later than in other countries where this type of training had been initiated earlier (CRUZ; POMBO; COSTA, 2008). The evaluation of the different programmes and their impact is a consequence of an increased offer of training, and the need to understand how GPs, for teachers, develop the interaction between training, research and teachers' practices (POMBO; COSTA, 2009).

When looking carefully into the qualification of human resources, the effectiveness and efficiency of educational systems have been questioned. Supported by the fact that training should be combined with professional development and, as such, requires a specialization suited to the needs arising from new professional profiles, impact assessment should be considered as an opportunity to promote reflection on these issues (PEREIRA; COSTA, 2004).

As a result of increased investment in both the creation and the development of master degree programmes, the evaluation of quality in GPs has become more carefully targeted (CRUZ; POMBO; COSTA, 2008). Evaluation establishes a close relationship with quality issues not only related to diagnosis, but also and especially regarding process improvement (PEREIRA; COSTA, 2004).

All training projects are designed to address specific needs, using activities in order to achieve their targeted goals. Thus, it is essential to establish the desired goals throughout the implementation of different project stages (ROLDÃO et al., 2000). These stages range from planning to impact (PEREIRA; COSTA, 2004), and the results achieved will determine the effectiveness of the project (ROLDÃO et al., 2000). Here, we focus precisely on the impact of such training, recognizing that the evaluation of training's impact is only one of the dimensions included in the evaluation of training (PEREIRA; COSTA, 2004). Therefore, we interpret impact as the consequences observed in a certain context, whether directly or indirectly, with a significant permanence that effectively contribute to changing that context (ROLDÃO et al., 2000).

Within this scope, the idea thatof evaluation becomes a component and a relevant practice for the improvement of individuals, programmes, institutions and society; 
thus, appealing to an active discussion of the relevant phenomena should not be overlooked (FERNANDES, 2010).

\subsection{Research design}

This research study, stemming from a qualitative paradigm, includes five distinct phases.

The first phase required the reading and analysis of questionnaires applied in the national study. The second phase included document analysis focusing on a description and categorization of the GPs curricular profiles most chosen by Portuguese teachers. The third stage of this study involved empirical work, namely two case studies. At this point we implemented a new questionnaire, in order to characterize the participating teachers and to identify those that had already completed GPs. After this, we conducted semi-directive interviews with these teachers as well as other players in leadership positions in these schools, followed by a new description and categorization of the GPs curricular profiles chosen by this subset of teachers. The literature review was conducted throughout the whole study.

Data collected during the different research phases was subject to content analysis, which is still ongoing, enabling the fourth phase to be a stage of reflection, articulation and integration of the results arising from the previous phases, thus allowing for the development of conclusions as to the real impact of teachers GPs at micro, meso, and macro levels.

In the fifth and final phase, considering the information resulting from the previous phases and analysing the impact of the GPs, it will be possible to develop proposals aimed at school administrations and curricular management for universities and schools geared towards enhancing the impact of teachers' GPs.

\section{Preliminary results}

In this section the initial results of two case studies will be presented, however only in terms of the perceptions of graduate teachers, but without references to the perspectives of leaders, which are also contemplated in the investigation. We will take into account the data from the questionnaires applied in both the School Cluster and the Private School as well as the interviews that were conducted. We will also include a short note about the analyses of some of the GPs curriculums provided by several of the participating teachers. 


\subsection{Population}

90 questionnaires were collected in the School Cluster allowing us to identify 43 teachers with GPs, of whom it was possible to interview 37. In the Private School, 55 questionnaires were collected allowing us to identify 17 teachers with GPs, out of whom 9 were interviewed.

\subsection{The graduate teachers}

Based on the analysis of data collected through the questionnaires, it is possible to make a brief characterization of the graduate teachers involved in the study.

If we begin this characterization with the identification of the highest degree acquired by the teachers interviewed, we observed that in the School Cluster, $53 \%$ of the participants had only attended one year of their master programmes, with this being equivalent to a specialization course, and the same percentage of master teachers was also observed in the Private School. In the first case, 35\% of the participant teachers had a master degree, $9 \%$ had finished their doctorate, and $2 \%$ did not identify the higher degree they had attained. $47 \%$ of the teachers in the Private School had only achieved a specialization course, and there were no teachers with doctorate degrees.

Concerning the educational area were the GP was completed, in both cases, Education was at the top with $47 \%$ in the School Cluster and $71 \%$ in the Private School. Also in the case of the School Cluster, $37 \%$ had enrolled in a disciplinary scientific field, and $14 \%$ had completed more than one GP having degrees in both fields, while $2 \%$ did not answer. In the Private School, 24\% had completed their programmes in a disciplinary scientific field, and $6 \%$ did not reveal the area in which they had completed their studies. Exploring this data, we realise that in the case of the school cluster, the dominating areas are school management and administration, pedagogical supervision, and educational communication and multimedia. In the case of the Private School, special needs training and school administration waswere the most prominent areas. Regarding GPs in a disciplinary scientific field, choices were characterized by a diversity of areas, ranging from history to science and mathematics, information and communication technologies, to linguistics, among others, with no particular prevalence of any in both studied cases.

The collected data allowed us to verify that the majority of teachers who had completed GPs in the School Cluster had between "21 and 31 years" of teaching experience, while in the Private School they were distributed across two brackets: 
between " 11 and 20 years" and " 21 and 30 years" of experience. Nevertheless, in both cases, teachers with fewer years of experience were the ones who had invested less in GPs training.

Regarding the variety of institutional positions held by graduate teachers working in the School Cluster, class director $(27 \%)$, project coordinator $(21.6 \%)$ and disciplinary group representative (10.8\%) were the most common. Conversely, in the Private School, in addition to teaching duties no reference was made to other positions, with only one of the teachers commenting on his function in educational support, another as a class director, one as a project manager and two as cycle coordinators.

As for the main reasons identified by the teachers for enrolling in a GP, among the School Cluster teachers the need to deepen and update their knowledge (13.5\%), personal affinity with a given topic (10.8\%) and personal fulfilment $(5.4 \%)$ were observed. For the Private School teachers, the most important reasons were: personal fulfilment (44.4\%), and the improvement of professional practice (33.3\%).

Regarding the preferred institutions for their GP training, for the School Cluster teachers the most chosen institutions were Universidade Aberta (Open University), and the Faculdade de Ciências (Faculty of Science), and the Instituto de Educação of the Universidade de Lisboa (Institute of Education of the University of Lisbon). For the teachers from the Private School the most chosen institutions were the Escola Superior de Educação of the Instituto Politécnico de Leiria (College of Education of the Leiria Polytechnic Institute), and the Faculdade de Motricidade Humana of the Universidade de Lisboa (Faculty of Human Kinetics, University of Lisbon).

\subsection{General perceptions on GPs}

Considering the interviewed graduate teachers' opinions and reflections on the importance of GPs, in the School Cluster case they were unanimous as to the relevance of this training, in terms of the update of knowledge being essential for a better professional performance. Nevertheless, at the same time they pointed out the lack of formal recognition by the school system for the added value that this highly qualified training represented for the school. The teachers from the Private School also made reference to the importance of graduate training, but considered that the excess of administrative demands might be at the root of overall lack of motivation, regarding a reduction of the importance given to this issue. The contribution of GPs was also mentioned as important, not only for the individual involved, but also for those with whom they work. 


\subsection{Perceptions on the quality of training and the curriculum}

Focusing our attention on the respondents' perceptions of the quality of training and curriculum they experienced, we discuss some of the most relevant data for these issues. Thus, as may be observed through the data already analysed, most graduate teachers from the School Cluster expressed a positive opinion on the GPs, mentioning that they arewere well structured, organized and of high interest. However, they also emphasized the high demands required and excessthe excessive emphasis on theory to the detriment of practice.

In their reflection on GPs, the Private School and School Cluster teachers mentioned the fact that they were well structured, which had allowed them to attain overall good training. Nevertheless, the majority of the Private School teachers added that the training they had concluded was well balanced in terms of theory and practice. With regard to the favourable opinions expressed by the School Cluster teachers regarding their training, in addition to the entire surrounding process, they emphasised the quality of the professors who had taught the different courses and had accompanied them through their academic paths $(29.7 \%)$, the knowledge acquired $(18.9 \%)$ and the established interpersonal relationships (16.1\%). Concerning the positive opinions expressed in this context by the Private School teachers, $66.6 \%$ of respondents emphasized the importance of having joined these specializations, $67 \%$ the acquired knowledge, and $44.4 \%$ the dynamics experienced at different times at the University, and also the quality of the university teachers who had accompanied their trajectories (33.3\%).

Nevertheless, the participating teachers in both cases were also able to point out some less favourable aspects of their GPs. They mentioned the lack of depth with which certain topics and contents were presented $(11.2 \%$ of the participants from the School Cluster and 10\% of Private School teachers) and also the limitations and barriers encountered when trying to successfully complete a degree while working full time in school as less positive aspects. This latter issue was mentioned by $35 \%$ of participants teaching in the School Cluster and $15 \%$ of respondents from the Private School. In the School Cluster there were also several teachers (11\%) who criticized the malfunctioning of courses and universities they had attended.

\subsection{Teachers' perceptions on the impact of GPs}

Analysing the personal and contextual effects of this training, for the School Cluster teachers the consequences mentioned tended to focus primarily on enrichment and personal fulfilment (32.4\%), development of cognitive skills (19\%), a career 
bonus $^{5}(13.5 \%)$, self-esteem $(10.8 \%)$ and better preparation to react in different contexts (10\%). However, only $33.3 \%$ of the Private School teachers mentioned self-satisfaction (at a personal level). At this point, it should be noted that this level of analysis was not initially contemplated in the research objectives, but emerged as a result of the collected data and resulting from its relevance and interest regarding the effects of GPs. Focusing now on the first level of analysis - the classroom (micro-impact) -, preliminary results point, in the case of the School Cluster, to changes in the methods of teaching several contents $(21.6 \%)$, their broader and more substantiated knowledge (10.8\%) and classroom dynamics (8\%). As for the Private School teachers, this training was reflected especially in the way of addressing the subjects (89\%) and their own preparation (77.7\%), considering themselves to be better prepared after completion of training.

At the school level (meso-impact), the effects of this training are essentially conveyed, in both cases, through requests to join specific school projects (a shared reality for $5.4 \%$ of graduate teachers from the School Cluster and $44 \%$ from the Private School); their institutional participation and action (13.5\% of teachers from the School Cluster and 33\% from the Private School); their knowledge application (13.5\% of respondents from the School Cluster and 44\% from the Private School). Collaborative work and involvement with colleagues are also two remarkable effects at this level $(10.8 \%$ in the School Cluster and $33 \%$ in the Private School).

The School Cluster teachers' voice regarding the impact of GPs on their educational and research contexts (macro-impact) was mainly reflected in the collaboration among the School, the University, and other institutional partners for the implementation of projects $(18.8 \%)$, in the research conducted by these teachers $(10.8 \%)$, and in public presentations $(8 \%)$. However, there was no recorded impact at this level reported by the Private School teachers.

\subsection{Teachers' suggestions and proposals}

The aim of this research is to leave a set of recommendations for universities and schools that could serve as a motto for reflection on the design of GPs for teachers to enhance the impact of such training for schools and consequently for student learning. In this context, the participating teachers were asked to make proposals that could enhance the effects of GPs on teachers and schools. Here, we will present some of their suggestions for the School, University, and Ministry levels.

5 There is no career bonus for the accomplishment of a graduate course. 
With regard to suggestions by all respondents from the School Cluster regarding the School level, they emphasised the need for greater collaboration among colleagues, as well as the promotion of peer work and peer training; holding informal gatherings and conferences on diverse reflection topics; examining and disseminating the GPs of the different teachers, as well as mobilizing these teachers to engage in tasks and institutional positions, on the basis of their developed skills, thus implying further reflection and action on how schools are organized. This last suggestion was also highlighted by respondents of the Private School, who added the importance of creating opportunities for the sharing and discussion of knowledge, the reduction of working hours, and the need to motivate teachers to enrol in GPs.

Considering the suggestions proposed by the School Cluster participating teachers for the University, many referred to the need for further reflection on the structuring of teacher training, and improved connections and relationships between the School and the University, the latter also shared by the participants from the Private School who also added the need to reduce administrative tasks.

As far as Suggestions for the Ministry are concerned, the need to provide financial support (for example, grants, sabbaticals) to promote GPs training was the most mentioned. On this level, the participating School Cluster teachers also suggested the attribution of new functions within the school, as well as the need for the Ministry to visit schools in order to gain awareness of the multiplicity of contexts encountered by teachers ${ }^{6}$.

\section{Final consideration}

Studying the reasons that led teachers to attend different GPs is essential in order to understand and question the multiple dimensions of curriculum and teachers' professional practices. This research aims to contribute and expand the knowledge on this issue, based on empirical data, associated with the return on investment for GPs and its impact on the three established levels: classrooms, schools and educational and research practices, adding here a fourth level of analysis - the personal impact - as a consequence of the results obtained.

Based on the preliminary results of this research, and considering only data from the analysis of questionnaires and interviews, in the institutions under study, there is a general tendency towards to a reduced impact of GPs training at the different

\footnotetext{
6 We have not so far presented any results on the impact of graduate courses on students' learning, because we have not yet completed the analysis of the data.
} 
levels. We cannot, however, overlook the reasons behind these teachers' decision to return to University, which are closely related, above all, to their personal fulfilment, without great professional expectations.

Another conclusion emerging from the analysis points to the need teachers feel to capitalize on these training courses, a need shared by the majority of respondents in both cases. This may be observed through how they suggest mobilization to other institutional positions where their developed skills can be placed at the service of students, schools and the community.

In this article we only present some considerations and research results. However, the importance of this study in the field of theory and curriculum development related to teacher training, contemplates an in-depth insight on the impact of the curriculum itself on a diverse set of professional practices.

In conclusion, the main aim of this research is to leave reflection guidelines for teacher training models and the effectiveness of GPs when the targets of such training are field practitioners. 


\section{O impacto da formação pós-graduada nos professores e nas escolas - dois estudos de caso: as perceções dos professores pós-graduados}

\section{Resumo}

O estudo aqui apresentado tem como problema central estudar o impacto da Formação Pós-Graduada (FPG) num conjunto de professores do Ensino Básico e do Ensino Secundário ${ }^{8}$ em Portugal. Pretendemos compreender se os professores consideram essa formação como uma mais-valia e em que medida isso se traduz na melhoria do seu desempenho profissional, das escolas e das aprendizagens dos alunos. Os resultados preliminares da investigação revelam, entre outros aspetos, que os motivos que levam os professores a fazerem FPG estão associados sobretudo a questões de realização pessoal e apontam para o reconhecimento da importância da FPG por parte dos professores $e$ das lideranças, no entanto com poucos efeitos.

Palavras-chave: Formação pós-graduada. Professores. Avaliação do impacto. Currículo.

\footnotetext{
7 O Ensino Básico compreende três ciclos: $1^{\circ}$ ciclo que tem a duração de quatro anos - do $1^{\circ}$ ao $4^{\circ}$ ano de escolaridade - frequentado por crianças a partir dos 6 anos de idade; $2^{\circ}$ ciclo que contempla o $5^{\circ}$ e $6^{\circ}$ anos de escolaridade normalmente frequentado por crianças entre os 10 e os 11 anos de idade; $3^{\circ}$ ciclo que integra $07^{\circ}, 8^{\circ}$ e $9^{\circ}$ anos de escolaridade frequentado, maioritariamente, por crianças entre os 12 e os 14 anos de idade.

8 O Ensino Secundário tem a duração de três anos $-10^{\circ}, 11^{\circ}$ e $12^{\circ}$ anos - frequentados, normalmente, por jovens adolescentes entre os 15 e os 17 anos de idade.
} 


\section{El impacto de la formación de postgrado en profesores y escuela - dos estudios de caso: percepciones de profesores postgraduados}

\section{Resumen}

El estudio que aquí se presenta tiene como problema central estudiar el impacto de la Formación de Postgrado en un conjunto de profesores de Educación Básica ${ }^{9}$ y Educación Secundaria ${ }^{10}$ en Portugal. Tenemos la intención de comprender si los profesores consideran esta formación como un valor añadido y en qué medida esto se refleja en la mejora de su desempeño profesional, de las escuelas y del aprendizaje del estudiante. Los resultados preliminares de la investigación muestran, entre otras cosas, que las razones por las que los profesores hacen Formación de Postgrado se asocian principalmente con cuestiones de realización personal y apuntan al reconocimiento de la importancia de la Formación de Postgrado por parte de los profesores y líderes, aunque con pocos efectos.

Palabras clave: Formación de postgrado. Profesores. Evaluación de impacto. Currículo.

\footnotetext{
9 La Educación Básica comprende tres ciclos: $1^{\circ}$ ciclo tiene una duración de cuatro años - del $1^{\circ}$ al $4^{\circ}$ grado - asisten niños de 6 años de edad; $2^{\circ}$ ciclo que incluye los $5^{\circ}$ y $6^{\circ}$ años de estudio, y es generalmente frecuentado por niños de entre 10 y 11 años de edad; $3^{\circ}$ ciclo que integra los $7^{\circ}, 8^{\circ}$ y $9^{\circ}$ grados, y es frecuentado principalmente por niños de entre 12 y 14 años de edad.

${ }^{10}$ La Educación Secundaria tiene una duración de tres años $-10^{\circ}, 11^{\circ}$ y $12^{\circ}$ años - y es frecuentada habitualmente por jóvenes entre los 15 y los 17 años de edad.
} 


\section{Referências}

BARBIER, J. A avaliação em formação. Porto: Afrontamento, 1985.

BRASIL. Ministério da Ciência, Tecnologia e Ensino Superior. Evolução do programa de desenvolvimento do Ensino Superior, 2010 - 2014. Brasília, DF: MCT, 2010. Available in: <http://www.mctes.pt/archive/doc/evolucao contrato_conf_ES_10set2010_final.pdf>.Access: 10 jun. 2016.

CAMPOS, B. Formação contínua e pós-graduação de professores em Portugal. In: GOMEZ, J.; BAPTISTA, V. (Ed.). Educar, sem fronteiras: educação e formação de professores em Espanha e Portugal: livro de atas do I Encuentro Hispanoluso de educación. Huelva: Universidade de Huelva, 1995. p.145-60.

CARR, W. Reconstructing the curriculum debate: as editorial introduction. Curriculum Studies, v. 1, n. 1, p. 5-9, 1993.

CORBETT, J.; NORWICH, B. Common or specialized pedagogy? In: NIND, M. et al. (Eds.). Curriculum and pedagogy in inclusive education: values into practice. London: Routledge Falmer, 2005. p. 13-30. (Values into practice).

CRUZ, E.; POMBO, L.; COSTA, N. Dez anos (1997-2007) de estudos sobre o impacto de cursos de mestrado nas práticas de professores de ciências em Portugal. Revista Brasileira de Pesquisa em Educação em Ciências, v. 8, n. 1, 2008.

CUNHA, A. Ser professor: bases de uma sistematização teórica. Braga: Casa do Professor, 2008.

. Experimentar Bolonha: testemunhos de uma experiência. In:

VIEIRA, F. (Org.), Transformar a pedagogia na universidade. Santo Tirso: De Facto, 2009. p. 79-95.

CURY, C. Graduação/ Pós-graduação: a busca de uma relação virtuosa. Educação \& Sociedade, v. 25, n. 88, p. 777-93, out. 2004. doi:10.1590/S0101-73302004000300007

DOYLE, W. Curriculum and pedagogy. In: JACKSON, P. W. (Ed.). Handbook of research on curriculum. New York: Macmillan Library Reference, 1992. p. 486-516.

ESTEVES, M. Para a excelência pedagógica no ensino superior. Sísifo: Revista de Ciências da Educação, n. 7, 101-10, set./dez. 2008. 
ESTRELA, M. Complexidade da epistemologia do currículo. In: LEITE, C. et al. (Orgs.). Políticas, fundamentos e práticas do currículo. Porto: Porto Editora, 2011. p. 29-36.

FERNANDES, D. Avaliação de programas e de projectos pedagógicos. In: SAPIENS 2009 - CONGRESSO INTERNACIONAL DE EDUCAÇÃO, 8., 2009. Available from: <http://repositorio.ul.pt/bitstream/10451/5885/1/ Avaliac $\%$ CC $\%$ A $7 \mathrm{a} \% \mathrm{CC} \% 83 \mathrm{o} \% 20 \mathrm{de} \% 20$ Programas $\% 20 \mathrm{e} \% 20$ Projetos $\% 20$ Pedago\%CC\%81 gicos.pdf $>$. Access: 15 jun. 2016.

FERNANDES, D. Acerca da articulação de perspectivas e da construção teórica em avaliação educacional. In: AFONSO, A.; ESTEBAN, M. (Orgs.). Olhares e interfaces: reflexões críticas sobre a avaliação. São Paulo: Cortez, 2010. p. 15-44.

FITZPATRICK, J.; SANDERS, J.; WORTHEN, B. Program evaluation: alternative approaches and practical guidelines. 3. ed. Boston: Pearson, 2004.

GASPAR, M.; ROLDÃO, M. Elementos do desenvolvimento curricular. Lisboa: Universidade Aberta, 2007.

GRESS, J.; PURPEL, D. (Ed.). Curriculum: an introduction to the field. United States of America: Clutchan, 1978.

JESUS, A. R. Currículo e educação: conceito e questões no contexto educacional. In: CONGRESSO NACIONAL DE EDUCAÇÃO, 8.; CONGRESSO IBERO-AMERICANO SOBRE VIOLÊNCIAS NAS ESCOLAS, 3., 2008, Curitiba. Anais... Curitiba, Pontifícia Universidate Cartólica do Paraná, 2008. p. 2638-51.

LEITE, C. Percursos e tendências recentes da formação de professores em Portugal. Educação (Porto Alegre), v. 28, n. 3, p. 371-89, set./dez. 2005.

- A formação de professores em Portugal e a

Declaração de Bolonha. Porto: Universidade de Aveiro, 2003.

Available from: $<$ http://paco.ua.pt/common/bin/Bolonha/

BOLONHA_A\%20 Forma $\% \mathrm{C} 3 \% \mathrm{~A} 7 \% \mathrm{C} 3 \% \mathrm{~A} 3 \mathrm{o} \% 20$ Professores $\% 20$ em\%20Portugal\%20Prof.\%20Carlinda\%20Leite.pdf $>$. Access: 18 jun. 2016.

LEWIS, S. Curriculum planinning for better teaching and learning. 4. ed. Austin: Holt, Rinehart and Winston, 1902. 
PACHECO, J. Teoria curriculares: políticas, lógicas e processos de regulação regional das práticas curriculares. In: SEMINÁRIO "O CURRÍCULO REGIONAL", 2003, Açores. Available from: <http://webs.ie.uminho.pt/jpacheco/ files/curriculoRegional.pdf>. Access: 21 jun. 2016.

PERALTA, M. Currículo: o plano como texto: um estudo sobre a aprendizagem da planificação na formação inicial de professores de alemão. Lisboa: Fundação Calouste Gulbenkian/Fundação para a Ciência e Tecnologia, 2005.

. Inovação curricular: a propósito do projecto metas de aprendizagem. In: COLÓQUIO DA SECÇÃO PORTUGUESA DA AFIRSE: REVISITAR OS ESTUDOS CURRICULARES - ONDE ESTAMOS E PARA ONDE VAMOS?, 19., 2012, Lisboa. Atas... Lisboa: Faculdade de Psicologia e de Ciências da Educação da Universidade de Lisboa, 2013.

PEREIRA, G.; COSTA, N. A construção de conceitos sobre avaliação do impacto da formação: um primeiro passo para a acção. In: COLÓQUIO DA SECÇÃO PORTUGUESA DAAFIRSE: REGULAÇÃO DA EDUCAÇÃO E ECONOMIA - ORGANIZAÇÃO, FINANCIAMENTO E GESTÃO, 13., 2004, Lisboa. Atas... Lisboa: Faculdade de Psicologia e de Ciências da Educação da Universidade de Lisboa, 2005.

POMBO, L.; COSTA, N. Avaliação de impacte de cursos de mestrado nas práticas profissionais de professores de ciências: exemplos de boas práticas. Investigações em Ensino das Ciências, v. 14, n.1, p. 83-99, 2009.

POUZADA, A. et al. Articulação formação graduada: formação pós-graduada: uma proposta de reflexão para o Conselho Académico da Universidade do Minho. Minho, 2003. Available from: < http://www.cac.uminho.pt/docs/gp-fgpg.pdf $>$. Access: 20 jun. 2016.

REIS, P.; CAMACHO, G. A avaliação da concretização do processo de Bolonha numa instituição de ensino superior portuguesa. Revista Española de Educación Comparada, v. 15, 41-59, set. 2009.

ROLDÃO, M. Gestão curricular: fundamentos e práticas. Lisboa: Ministério da Educação, 1999.

(Coord.). Formação e práticas de gestão curricular: crenças e equívocos. Porto: Edições ASA, 2005. 
ROLDÃO, M. et al. Avaliação do impacto da formação: um estudo dos Centros de Formação da Lezíria e Médio Tejo 1993-1998. Lisboa: Colibri, 2000.

SACRISTÁN, J. O currículo: uma reflexão sobre a prática. 3. ed. Porto Alegre: Artmed, 2000.

TRINDADE, R. O Ensino Superior como espaço de formação: do paradigma pedagógico da aprendizagem ao paradigma da comunicação. In: LEITE, C. (Org.). Sentidos da pedagogia no ensino superior. Porto: CIIE/ Livpsic, 2010. p. 75-98.

VIEIRA, F. Transformar a pedagogia na universidade? Currículo sem Fronteiras, v. 5 , n. 1 , p. $10-27$, jan./jun. 2005

VIEIRA, F.; SILVA, J.; ALMEIDA, J. Transformar a pedagogia na universidade: possibilidades e constrangimentos. In: VIEIRA, F. (Org.) Transformar a pedagogia na universidade. Santo Tirso: De Facto, 2009. p. 17-35.

ZABALZA, M. Planificação e desenvolvimento curricular na escola. 6. ed. Porto: ASA, 2001.

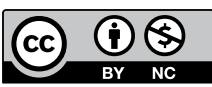

\section{Informações das autoras}

Ana Rita Faria: Master Degree in Sciences of Education, Instituto de Educação da Universidade de Lisboa. Contato: a.rita_faria@hotmail.com

Pedro Guilherme Rocha dos Reis: Ph.D., Associate Professor in Instituto de Educação da Universidade de Lisboa. Contato: preis@ie.ulisboa.pt

Maria Helena Peralta: Ph.D., Assistant Professor Retired in Instituto de Educação da Universidade de Lisboa. Contato: hperalta@ie.ulisboa.pt 